
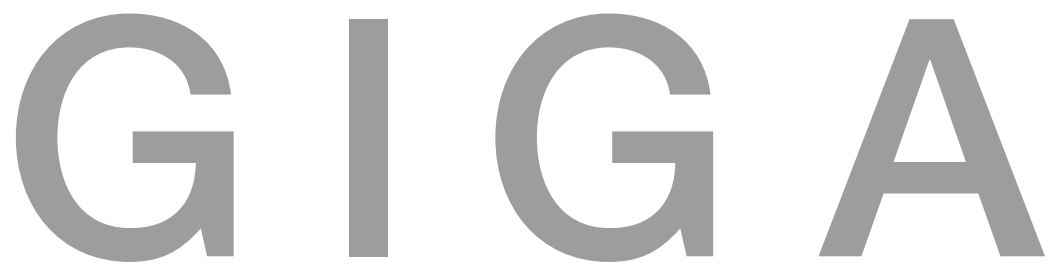

Working

German

Institute of Global and Area Studies Papers

Leibniz-Institut für Globale und Regionale Studien

GIGA Research Programme:

Transformation in the Process of Globalisation

The Emergence of a

New 'Socialist' Market Labour Regime in China

Jutta Hebel / Günter Schucher

$\mathbf{N}^{\circ} 39$

December 2006 


\section{GIGA Working Papers}

Edited by GIGA German Institute of Global and Area Studies / Leibniz-Institut für Globale und Regionale Studien.

The Working Paper Series serves to disseminate the research results of work in progress prior to publication to encourage the exchange of ideas and academic debate. An objective of the series is to get the findings out quickly, even if the presentations are less than fully polished. Inclusion of a paper in the Working Paper Series does not constitute publication and should not limit publication in any other venue. Copyright remains with the authors. When Working Papers are eventually accepted by or published in a journal or book, the correct citation reference and, if possible, the corresponding link will then be included in the Working Papers website at:

www.giga-hamburg.de/workingpapers.

GIGA research unit responsible for this issue: Research Programme 'Transformation in the Process of Globalisation'

Editor of the GIGA Working Paper Series: Bert Hoffmann <hoffmann@giga-hamburg.de> Copyright for this issue: ( ) Jutta Hebel and Günter Schucher

Editorial assistants and production: Verena Kohler and Vera Rathje

All GIGA Working Papers are available online and free of charge at the website: www.giga-hamburg.de/workingpapers. Working Papers can also be ordered in print. For production and mailing a cover fee of $€ 5$ is charged. For orders or any requests please contact:

E-mail: workingpapers@giga-hamburg.de

Phone: ++49 (0)40 - 42825548

GIGA German Institute of Global and Area Studies /

Leibniz-Institut für Globale und Regionale Studien

Neuer Jungfernstieg 21

20354 Hamburg

Germany

E-mail: info@giga-hamburg.de

Website: www.giga-hamburg.de 


\title{
The Emergence of a New ‘Socialist' Market Labour Regime in China
}

\begin{abstract}
China's transition to a market economy has been a process of basic institutional changes and institution building. The institutional change from a socialist labour regime (SLR) as one of the backbones upholding the traditional leninist system to a new 'socialist' market labour regime (SMLR) became particularly important for the success of economic and political reforms. This analysis is based on the analytical framework of regimes and makes use of the idea of path dependence. An ensemble of institutions, mutually interconnected and influencing each other, forms the regime and shapes its trajectory. Six institutions are identified to constitute the employment regime: (1) the system of social control, (2) the production system, (3) the system of industrial relations, (4) the welfare system, (5) the family order, and (6) the educational system. The SMLR is still characterised by its socialist past and differs from other varieties of transformation labour regimes and bears little resemblance to labour regimes in Western market economies.
\end{abstract}

Key words: China, institutional change, transition, labour market, employment regime, path dependence

JEL classification: B52, J08, J40, P36

\section{Dr. Jutta Hebel}

was assistant professor at the Institute of Rural Development, Georg August University Göttingen. Her research focuses on development sociology and labour market sociology. Contact: jhebel@gwdg.de

\section{Dr. Günter Schucher}

is director of the GIGA Institute of Asian Affairs in Hamburg. His research focuses on social issues in the PRC, especially at the Chinese labour market as well as at cross-Strait relations. Dr. Schucher is the treasurer of the German Association of Asian Studies and editor of the refereed journal ASIEN.

Contact: schucher@giga-hamburg.de, website: http://staff.giga-hamburg.de/schucher 
An earlier version of this paper was presented at the workshop on 'Labor Mobility in Urban China - An Integrated Labor Market in the Making?', Hohai University, Nanjing, Jiangsu Province, PR China, 1-2 September 2005. We would like to thank the organizers (Prof. Shi Guoqing, Hohai University; Dr. Michaela Baur, GTZ Nanjing; Prof. Jin Yihong, Nanjing Normal University; Mr. Roland Feicht, FES; Prof. Bettina Gransow, Free University Berlin) for this opportunity and the participants of that workshop as well as our colleagues from GIGA, PD Dr. Wolfgang Hein and Dr. Margot Schüller, for their very helpful comments.

\section{Zusammenfassung}

\section{Die Entstehung eines neuen „sozialistischen“ marktwirtschaftlichen Beschäftigungs- regimes in China}

Die Entstehung einer Marktwirtschaft in der VR China ist ein tief greifender Prozess institutionellen Wandels. Der Wandel von einem sozialistischen Beschäftigungsregime, das zu den Stützen des traditionellen leninistischen Systems gehörte, hin zu einem neuen „,sozialistischen“ marktwirtschaftlichen Beschäftigungsregime ist dabei von besonderer Bedeutung für den Erfolg der wirtschaftlichen und politischen Reformen. Für die Analyse dieses Prozesses wird in diesem Paper der Regimeansatz vorgeschlagen, der das weitgehend national verfasste Beschäftigungsregime als ein Ensemble von Institutionen auffasst, die miteinander verbunden sind und sich gegenseitig beeinflussen. Sechs Institutionen werden betrachtet: (1) das System sozialer Kontrolle, (2) das Produktionssystem, (3) das System der Arbeitgeber-Arbeitnehmer-Beziehungen, (4) das Wohlfahrtssystem, (5) das Haushaltssystem und (6) das Bildungssystem. Das so konstitutierte Beschäftigungsregime entwickelt eine Eigendynamik mit pfadabhängigen Wandlungsmustern. Die „sozialistische“ marktwirtschaftliche Ordnung trägt daher immer noch Züge der sozialistischen Vergangenheit und unterscheidet sich von den Beschäftigungsregimen anderer Transformationsländer und westlicher Marktwirtschaften. 


\title{
The Emergence of a New ‘Socialist' Market Labour Regime in China
}

\author{
Jutta Hebel and Günter Schucher
}

\section{Article Outline}

1. Introduction

2. The Labour Process under Discussion: Labour Regime and Path Dependence

3. Characteristics of the Socialist Labour Regime (SLR)

4. The Emerging 'Socialist' Market Labour Regime (SMLR)

5. Conclusion: Insights from the Transition of a Labour Regime

\section{Introduction}

China's transition to a market economy - albeit a market economy with Chinese characteristics - has primarily been a process of basic institutional changes and institution building. It is well known that no blueprint existed for remodelling the set of institutions during the transition process. As China launched its reforms at the end of the 1970s, the necessity of increased economic growth was not contested; fundamental struggles did however arise over how the process should be guided. Controversial positions were put forth; some of them advocated increases in efficiency and productivity within the institutional framework of the planned economy on the one end and others supported changes to the institutional set in line with market conditions on the other. What ensued was a type of trial and error process, involving a good number of experiments. With the acceleration of the reforms, the more conservative positions in favour of continued economic planning and state control were overridden. 
Institutional change has a considerable impact on the economic performance of transition economies. Following initial reforms in the agricultural sector, the Chinese leadership focussed on restructuring the enterprise institutions, i.e., state and collectively owned enterprises, in an effort to increase economic growth. Moving enterprise institutions away from central planning implied the implementation of reforms that would make the allocation and reallocation of labour more flexible. The changes in labour (market) institutions became particularly important for the success of economic reforms, since they could act as catalysts or obstacles to change as well. This proved to be all the more true as China exposed its economy to the world market.

The socialist-type organisation of labour, however, has been one of the backbones upholding the socialist system. Therefore, the organisation of labour is a highly strategic field and one that has experienced remarkable changes. The state and the CCP exercised their power by controlling work relations and defining people's livelihoods. One may even hypothesize that the state's monopoly over labour allocation and reallocation (jobs), combined with the exclusive distribution of basic resources (food, housing and welfare), might have had a deeper impact on people's compliance with the socialist system than its direct political control. For this reason, changes in the organisation of labour and its related institutions are of crucial importance for both the economic and political systems.

In this contribution we will scrutinize the institutional change from a socialist labour regime to a 'socialist' market labour regime. In contrast to the term "socialist", which points to the traditional leninist system established after 1949 and is being transformed since the beginning of the reforms in 1978, we use 'socialist' coined by the Chinese leadership in 1992 and used in expressions like 'socialist market economy', to characterize the hybrid system of the transition period. On the one hand 'socialist' refers to the official Chinese paradigm, which holds that institutions should have special 'Chinese characteristics', on the other hand it indicates that the labour regime is still so some extend characterised by its socialist past.

The phasing out of the planned labour system and the concurrent emergence of a labour market in China are not disputed phenomena per se. Yet, talking about a Chinese labour market does not necessarily imply any convergence into a kind of globally valid market model. This idea may be summarized in three main arguments: to begin, institutional change is not strictly determined by universal economic laws, but follows its own dynamics. Secondly, labour market policy - as any other policy - is constantly confronted with conflicting political goals, e.g., economic growth, political stability and social harmony that have to be reconciled. Family policy or social control may restrict reforms aiming at a higher employment rate and/or increases in productivity. And lastly, the inclusion of the population in the labour market is not the result of any single institution, but rather an outcome of an ensem- 
ble of institutions, varying among different countries, as well as within different demographic groups (e.g., gender, age, etc.).

Focussing on the macro-level of labour reforms, we will take this ensemble of institutions into account. Therefore, the subsequent analysis of changes in the Chinese labour institutions during the transition period will be based on the analytical framework of regimes. The concept of production regimes formed by a set of institutions has been proved to be effective in a number of contexts. The analytical concept was widely received with EspingAndersen's work on 'worlds of welfare capitalism' and the simultaneously commencing discussion of 'varieties of capitalism'. We draw on the ideas of a set of institutions and institutional complementarities that vary systematically across regimes - while remaining mindful of the debate on labour regimes that they induced. Moreover, we make use of the idea of path dependence in institutional change and examine some recent contributions that emphasize its analytical leverage. An ensemble of institutions, mutually interconnected and influencing each other, forms the regime and shapes its trajectory. The seemingly simplistic idea of 'history matters' is rather challenging when the proposed sensitivity to initial conditions has to be proved in the context of a complex set of institutions and their particular sequences.

The emphasis in this paper is on providing an integrative and rather reflective account of the main analytical issues. In the following section we will refer to the earlier debate on the labour process in the relevant literature and elaborate on the concepts of regime and path dependence and their relevance as analytical frameworks for labour. In section three we will outline relevant characteristics of the socialist labour regime as necessary background information for reconstructing the path-dependent labour process. Section four will scrutinize the emerging new 'socialist' market labour regime in China and elaborate its interrelatedness with the chosen set of institutions. In the final section we will summarize the Chinese example and draw some conclusions on the trajectory of the Chinese labour regime in particular as well as the regime concept in general.

\section{The Labour Process under Discussion: Labour Regime and Path Dependence}

There is both consensus and considerable dissent among scholars when it comes to the labour market debate on how labour market theories should address the labour process, labour exchange and unemployment. Different approaches agree in that supply of labour should match demand and that 'mismatches' between the two are the grounds for unemployment. Underlying reasons for 'mismatches' and unemployment are sought either on the 
supply side, the demand side or both. Changing job offers and work demand can thus result from a number of factors, such as economical restructuring, technological change and the rationalisation of production processes. Further factors include demographic development, level and type of qualification of the labour force or the degree of mobility and flexibility of the labour force.

All labour market theories offer varying explanations for labour market processes, including labour exchange, 'mismatches' and unemployment, which are based on their different basic premises and assumptions. For a long time, economic theories dominated the mainstream of the labour market discussion with a powerful analytic theory that relies on the assumption of a perfectly competitive market. Today, new concepts have been introduced into the debate that are more decidedly influenced by the social sciences and point to institutions and their particular role in shaping the labour market.

Leading neoclassical economic theories focus on the balance between the marginal product of labour and the wage level defining the efficiency of labour. Under competitive market conditions a state of equilibrium was expected to arise, albeit in the long run, which would affect adjustments in wage setting processes and the level of employment. Unemployment is explained as the failure to bring income demand into a balance with prices for work. In general, these economic theories refrain from analysing special characteristics of labour markets or pathways to the present state of a particular labour market. Using a powerful deductive apparatus, they conceptualise an abstract model of factor costs and prices that applies to all market economies. State intervention, subsidies or wage setting power of trade unions are viewed as distorting the basic function of economic laws. During the 1980s, institutional economics challenged pure economic perspectives, emphasising, for example, empirical analysis over abstract theorizing and stressing the fostering role of institutions in economic processes. Although institutions were taken into account, the basic assumptions of the institutionalist economic perspective did not transcend those of the pure economic concept. In opposition to the mainstream of labour market research, social scientists started to contribute their own theories and empirical research. The different sociological paths and phases of the international labour process debate cannot be summed up in their entirety within the scope of the present context. In many Western countries the study of work has been biased by Marxist theories for a long time. Working arrangements have been analysed exclusively within the system of capitalist production and class relations. Private ownership of the means of production ensured surplus appropriation and shaped the work relations. The pivotal studies of Braverman (1976), among others, influenced the later debate on the labour process (e.g., exploitation, degradation of work, Taylorism/Fordism and labour control in the workplace). Marxist analysis of capitalism and industrial work provided the 
framework for these studies and its assumptions guided their empirical research and findings. Consequently, the first aim of this type of research has been the detection of compliance with the laws of capitalism which standardize the labour process in all capitalist societies. The empirical discovery of diversity, explained for example by historical pathways, was generally not on the agenda. Varieties of capitalism have emerged only recently as a new field of research (Ebbinghaus and Manow 2001).

During the 1970s and 1980s, a number of American academics working along the disciplinary boundaries of economics and sociology began to investigate national characteristics of Western capitalist labour markets. Although still connected to Marxist assumptions, they developed new labour market concepts and contested the idea of a unified and competitive labour market. Instead they underlined exactly the opposite and stressed the dual character of labour markets and segmentation processes. The basic idea behind their work was that labour markets are split up into different segments that differ in their logic, including in such points as entry ports into the market, mobility and careers, and in the distribution of job rewards. These segments absorb dissimilar workforce groups who do not stand in direct competition with one another.

Various concepts of labour segments have been proposed. The different segments are either called primary and secondary segments, which represent different quality levels of jobs (contract security, work safety, wage level and qualification), or internal and external labour segments, highlighting processes of closure towards outsiders. Amending the latter concept and with reference to Germany, Lutz (1987) and Sengenberger (1978) paid special attention to the problems of qualification and described a closed internal segment of qualified labour. They termed the German labour market during the 1980s a 'firm-centred labour market' that excluded the low-skilled workforce from jobs in the inner segment. The insights offered by different versions of segmentation theory proved to be very fruitful for the analysis of labour markets. First of all it stood in fundamental opposition to the economic assumption of a single labour market. In showing the existence of segments, it did away with expectations of a pending equilibrium.

Since the 1980s, the concept has also been used as an analytical tool for the investigation of labour systems in transition countries, namely in Eastern Europe, e.g. Hungary (Galasi and Sziraczki 1985; Vodopivec 1991), the GDR (Grünert and Lutz 1994) and the PR China (Hebel and Schucher 1992; Jackson 1992; Yang 2002). Whereas explanations for segmentation processes in market economies draw on production regimes, human capital and training, job idiosyncrasies and the nature of work, the segmentation processes occurring in planned economies are identified as a result of state regulations, state strategies of production in the public sector, the management of human resources and socio-political population control. 
The driving forces behind segmentation processes and the emerging characteristics of the planned labour system differed clearly from those in Western societies. State planning and socio-political control in China produced several segments of urban labour force and separated it from the rural workforce. Despite different explanations, the concept proved to be a valuable framework for the analysis of centrally planned labour, highlighting the restrictions of the socialist 'labour system' (laodong zhidu).

In spite of these valuable insights, current scientific contributions have transcended the idea of segmentation. Segmentation theories remain attached to the attempt to elucidate universal causes for the creation of segments, be they economic or political. More recent concepts go beyond such unilateral perspectives and proffer instead new ideas taken from a broader debate on the institutional embeddedness of the labour process and employment. In clear contrast to economic theories, these sociological approaches emphasize the specific features of labour markets in each country and bring a set of institutions into play that emerged during extended historical periods and resulted from trade-offs between different values, goals and power constellations in the society.

The present 'face-lift' experienced by ideas on the embeddedness of social action is, nonetheless, not surprising. Social embeddedness is one of the foundations of sociological thought. Granovetter (1985) and others advocated the idea already during the 1980s. Like any other theoretical framework, the idea of embeddedness gained momentum from the critique of the one-sidedness of established concepts, in this case from Marxist and Post-Marxist theory. Instead of searching for sameness and convergence of labour processes, the new framework within the labour market debate intends to work out the national particularities of labour markets and highlight them through comparative analysis. A new term - labour regime - has been coined for this framework. It aims to express that a number of institutions in their entirety shape the labour market. Social institutions influence the values, norms and behaviour of people; and, on the macro-level, they define the labour process, labour participation and the role of gainful labour in any particular society. E.g., labour inclusion varies between different societies and throughout history due to particular institutions like family or welfare. The concept conceives the labour market as an outcome of the interplay between different institutions, each having its own particular rationale and history.

The present labour market debate parallels some other strands in academic discussions, namely on the welfare state (or welfare regime), the production regime or gender order (Pfau-Effinger 2001). Some authors have proposed regime typologies. The most famous contribution is Gøsta Esping-Anderson's analysis of the 'three political economies of welfare states' (Esping-Andersen 1990, 1994; Esping-Andersen and Regini 2000). He distinguishes three variations of welfare states in the Western capitalist world clustered into regime-types 
(social democratic, conservative and liberal welfare regime). The institutional set varies between different welfare regimes, in accordance with different arrangements between the state, the market, and the family. According to Esping-Andersen, the welfare state has a direct role in shaping many social institutions, the labour market being the most important of them. Therefore, labour markets are not only interwoven with social policy, but they also derive much of their logic from their particular embeddedness into the welfare state's institutional framework, leading to coincidence of welfare-state regimes and labour regimes (Esping-Andersen 1990).

Other authors have amended Esping-Andersen's inspiring contribution. Some comparative studies have challenged his proposed limitation to three worlds and pleaded for the additional worlds of a southern European or Mediterranean welfare state, a 'radical' antipodal welfare state or a Japanese case. Andreß and Heien (2001) added to the debate with their distinction between East and West Germany, drawing on the different cultural, structural and institutional background formed during the post-war period. Two different regime types emerged that had to be brought into accord after the reunification of the country. The former (East German) socialist welfare regime underlined the dominant role of the state, a high degree of de-commodification and a strategy of high labour inclusion, whereas the West German conservative model was based on the principle of subsidiarity, a low to medium level of de-commodification and segmentation.

A further theoretical attempt which utilizes the regime idea comes from the discussion on the East Asian welfare system (Goodman et al. 1998). The authors compare different East Asian countries and elaborate similarities and differences in welfare arrangements. They conclude that, despite national characteristics, a particular East Asian welfare model can in fact be discerned. Kim (2005) presents a critical review of the literature on welfare regimes with special emphasis on the East Asian welfare regime. He argues that Esping-Andersen's criteria provide only limited insights for the analysis of East Asian welfare states, when one considers the special relationship between high economic growth and low social welfare. The welfare regime 'typology' is inadequate for capturing the 'ever-changing welfare appearance of East Asian countries'. It would also be methodologically incorrect to use different attributes from Esping-Andersen and to add only a 'fourth regime' or to look for a solution by referring to a 'hybrid type' or an entirely different type. The solution that Kim suggests is to expand and reconstruct the welfare regime criteria. Besides the level of tax expenditure, Kim especially highlights the element of enterprise welfare.

In sum, the literature on labour regimes is not yet very well developed and still refers to the welfare regime typology. Together with other strands in the labour debate, the concept of labour regimes shares its special concern about the characteristics of particular labour mar- 
kets and reduces diversity into models. The inclusion of socialist regimes or regimes in less industrialised countries with large agricultural sectors is, however, lacking so far. The only exception has been the contribution by Andreß and Heien, who include the former East German welfare system, but do not elaborate the details. Especially the transition of socialist labour systems into labour markets has been neglected. Regime typology has remained a tool for cross-sectional analysis. The literature on varieties of capitalism also deals with the emergence of new types in Central and Eastern Europe - with a brief mention of China (e.g., Knell and Srholec 2006). In general, these writings assume that an achieved state of institutions shapes this development. In his comparative examination of the adaptation of labour institutions, Kong (2006) draws on the distinction between liberal market economies (LME) and co-ordinated market economies (CME) and analyses the adaptation of South Korea and Taiwan to globalization. He identifies distinct patterns of labour market liberalization among the so-called CME based on supplementary explanations emphasizing economic legacies and political logics.

This article will provide a first survey on the transition of the socialist labour regime in prereform China to a 'socialist' market labour regime. We understand changes of the labour market, adaptations to new challenges (e.g., globalisation, transition) and the extent of work inclusion as being 'path-dependent', i.e., framed by history, former solutions of labour exchange and the interplay of institutions. Each labour market follows a unique (national) trajectory supported by a set of institutions of that particular society. But how can such developments be assessed?

Pathways of institutional change are not determined strictly by the past. Instead of a deterministic perspective, the regime concept considers changes to be rather contingent. In order to overcome a widely-held, simplistic view on historical influences, valuable insights have been provided by recent contributions to path dependence. Ebbinghaus discusses the problem of 'when and how institutions evolve and why they change' (Ebbinghaus 2005: 6). The author distinguishes between diffusion and developmental pathways, the first theorem being an unplanned 'trodden trail' that emerges through a subsequent, repeated use of an initially chosen path. Developmental pathways are composed of an interdependent sequence of events and allow for 'road junctures'. Ebbinghaus states that an analysis must focus on the mechanisms that stabilize or destabilize the institutions in question; and, furthermore, a separation of the level of interaction between actors (micro-level) from the system-level of institutions (macro-level) is important. The interrelatedness of both levels is an issue for interdisciplinary research, thus enabling the identification of complementarities, interest politics, coordination or internalisation (Ebbinghaus 2005: 21). 
Page has provided additional fine tuning to the concept of path dependence. He emphasizes the importance of the implementation order of existing institutions, the historical or vertical context in contrast to the horizontal context of the set of strategic situations, and differentiates between several forms of historical dependence. He identifies processes in which only the set of past choices and the events in the past matter (which he calls phat or state dependence), setting them apart from path-dependent processes, in which not only the content, but the order and path of previous events are also significant. Path dependence requires 'a build-up of behavioural routines, social connections, or cognitive structures around an institution', and influences, directly or indirectly, peoples responses in the future. Exhibiting points of proximity to decision theory, Page emphasizes the necessity of research on the evidence of positive and negative externalities (Page 2006: 89, 111f.; Page and Bednar 2006: 7). Elaborating on the transition of the labour regime in China, we use labour regime as a generic term, which allows an entire set of institutional arrangements that influence the labour process to be deciphered. An institution is commonly defined as a set of norms forming an enduring behavioural pattern, which, in turn exerts social constraints on members of the society. Norms reflect or embody cultural values, are explicitly established or traditionally passed on and are followed as a result of socialization or backed by sanctions that promote conformity. A labour regime results from the interplay of specific institutions and has repercussions on all of them in return. The scope and limits of China's labour reforms are shaped by the set and order of related institutions.

To our knowledge, one fundamental problem has, however, been widely excluded from the debate: which institutions really matter? Even institutions having an adverse effect on economic performance often tend to persist for long periods of time (Bardhan 2005: 501). Some current literature in this area highlights various institutions that form and interact with the labour regime. For instance, Schmid (1996) lays out an ensemble of five institutions constituting the employment system: (1) the production system, (2) the system of industrial relations, (3) the welfare system, (4) the private household, and (5) the educational system. Although following Schmid's work, Heidenreich $(2000,2004)$ concentrates on three institutional orders: (1) the order of private ways of life, (2) the economic and production order, as well as (3) labour and social political institutions.

Our analysis will draw on the five institutions presented in the above literature. We will, however, add the system of social control as a sixth institution. Social control, especially in forms such as the hukou or household registration system, has been a core instrument of the Chinese communist party-state in controlling its population, stabilizing society and extracting resources from the countryside to feed industrialisation. We will describe these six institutions and attempt to elucidate their interrelatedness with the labour market. Fig. 1 pro- 
vides a schematic overview of the mutual interrelatedness of the six institutions with the labour regime.

Like Heidenreich, we prefer the term regime to system, as the latter implies unified and coherent structures of regulation. We understand regimes as patterns of traditions, past experiences and problem solutions as well as of current expectations, perceptions, behaviour and relations. In this contribution we will not present a further regime-type. Insights from the various contributions on welfare and labour regimes and their trajectories mentioned above can, however, help us to analyse and better understand the Chinese labour market and its ongoing changes. A certain arbitrariness remains in relation to the choice of the relevant institutions shaping the Chinese labour market. The choice will never be fully inclusive, as social reality is complex and undergoing continuous change. Moreover, the regime concept itself is in need of further theoretical refinement. To this effect, Crouch (2005) argues that, from an empirical standpoint, institutional heterogeneity in the different regime types is much higher than currently presumed by comparative research. Our purpose here is to give a initial general outline of the regime framework drawing on the transition of the Chinese labour market. We will refer to the above-mentioned literature and our own empirical evidence from earlier research in an effort to steer research in this direction.

\section{Fig. 1: Institutional Setting of the (Chinese) Labour Regime}

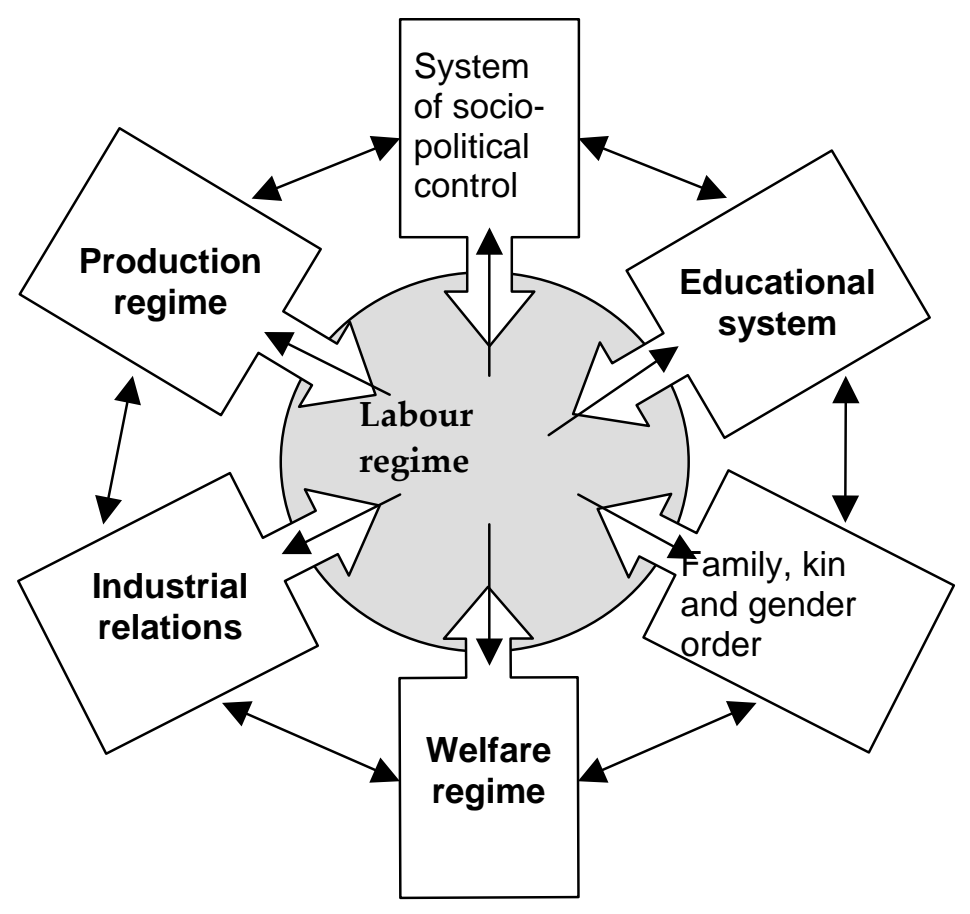




\section{Characteristics of the Socialist Labour Regime (SLR)}

As a necessary background, a brief outline of the pre-reform socialist labour regime (SLR in the following) will be given. The changes that occurred during the reform period were driven by both endogenous and exogenous factors. The official Chinese paradigm, which holds that institutions should have special 'Chinese characteristics' (e.g., 'market economy with Chinese characteristics') is very much in line with the basic assumptions of the regime concept. It paraphrases the embeddedness (in this case of the Chinese labour market) in a unique institutional setting with a particular pathway of changes. Traditional cultural and socialist elements inspire the logic of diverse institutions, such as the kinship and family system, industrial relations or the social security system.

With regard to the characteristics of the SLR, it must be pointed out that the divide between urban and rural employment is of outstanding importance. Similarly to some authors who warn against the analytical rigidities inherent to an approach which labels countries as having only one regime type, it may be argued that China actually had two different socialist labour regimes, an urban and a rural one, that are currently in the process of being integrated into a single 'unified' labour (market) regime. Leaving this differentiation to further studies, we will reduce complexity by modelling only one 'national' regime - at the risk of having an urban bias.

In contrast to rural areas, where farmers were more or less subjugated to the production discipline of rural collectives, urbanites have been integrated into a particular type of employment that we call a socialist normal work pattern (SNWP), adapted from the term Normalarbeitsverhältnis from the German labour market discussion. The SNWP is considered to be a normative pattern, since it has been institutionalised as a model for the life span of the urban population. This model is characterised by a number of elements, including enterprisespecific work training, work assignment by the labour bureau, a normal work life as a member of a work unit (danwei), enjoying danwei-related social security and benefits (such as housing, education, subsidies), regular retirement at a prescheduled age and retirement benefits provided by the danwei. The SNWP structured the course of life of Chinese individuals into three major phases of work: preparation, full and stable employment and a post-retirement period.

The Chinese express this pattern with the well-known metaphor of the 'iron rice bowl'. Seen from a societal perspective, this model served as a core means to stabilise society and control the urban populace. From an individual perspective, the SNWP had a considerable impact on the whole life course. It determined work aspiration, motivation, training and job satisfaction. Life expectation was centred on work and danwei membership. Membership in the 
danwei was not confined to work relations (based on contracted time and work), but radiated into the private lives of people, interfering even in marriage and family planning. Personal relations were, as such, interwoven with work relations and vice versa.

The pre-reform SNWP was dominated by the state, to the exclusion of almost all market activities. The state held a monopoly on work allocation and employment as well as wage setting within its planning system. Social control dominated the logic of employment relations and took its toll on mobility and flexibility in the labour process. The clear-cut rural-urban divide and rigid migration controls are only the most obvious symptoms of the SLR.

The SLR has been upheld by a set or, in other terms, a mix of institutions. All these institutions follow a specific, tradition-based logic, in addition to various other factors, including the Western socialist ideology which relies on Marx's fundamental analysis of capitalism. The institutions we present here shape the SLR, the urban SNWP and rural exclusion from the urban labour market. This set of six will be briefly described in the following.

First, the socio-political control of the Chinese population refers to any practice on the part of the state which aims to secure individual compliance, maintain collective order and deal with deviant situations. Order was mainly enforced by rigidly dividing rural and urban areas via household registration (hukou) and food rationing. The comprehensive integration of rural residents into the rural collective units (communes, production brigades and teams) and urban residents into work units (danwei) were further measures in this direction (Shaw 1996; Wang 2005). Without going into historical detail, the institutions of population control incorporated not only socialist, but also traditional elements, such as the rural baojia system. Political institutions, namely the hukou system and work units (danwei), were instrumental in establishing the rural-urban divide, a chasm which has been crucial for the Chinese socialist labour regime (Putterman and Dong 2000: 410f.). These institutions were directed at controlling population mobility and institutionalised the exclusion of the rural population from the urban labour market, thus generating an uneven regional development. They gave rise to a segmented labour system, dividing the Chinese workforce into a privileged urban population with the possibility of realizing the SNWP and a rural majority essentially chained to rural areas. The rural-urban duality still influences China's political economy today.

Second, the SLR corresponded largely with production planning and the production process, adapted from the Stalinist model of industrialisation (Pei 2005). The established SLR relied on state-led industrialisation, a high rate of investments concentrated in heavy industry and a vast surplus of labour in agriculture at the expense of low urban wages and rural incomes. The public sector was funded by the state and absorbed the majority of the urban labour force. State-induced labour immobility and work force placement on the part of planning institutions were factors that created the well-known labour redundancy on a larger scale. The 
socialist planned economy was based on what Kornai (1980) called 'soft budget constraints' and allowed enterprises to organize their labour process by expanding their work force far beyond the limits of profitability. Moreover, state-owned enterprises often pursued strategies of over-manning and labour-consuming production strategies since their prestige increased with the sheer number of their workforce thus improving their access to resources. This practice of non efficient labour allocation was combined with a policy of low and equal wages (Hebel 1997; Tomba 2002).

Third, trade unions played a special role in the SLR. Directly after the declaration of the PRC, the CCP moved rapidly to monopolise working class organisation and to promulgate a Trade Union Law. The basic intentions of these actions were the reduction of worker unrest and control of labour in a top-down, management-backed policy. The role ascribed to the All China Federation of Trade Unions (ACFTU) emulated Soviet-style policy and socialist ideology. Because workers were considered the owners of the means of production and masters of the enterprise, no particular type of worker protection was viewed as being necessary. On the one hand, trade unions in China were political institutions, organisationally bound to the CCP and state-owned enterprise (SOE in the following) management and supposed to transmit the politics of the party state (the idea of unions acting as 'transmission belts'). On the other hand, trade unions were social institutions responsible for welfare arrangements at the grassroots level. The comprehensive provision of welfare to dependent danwei workers has been connected to the basic level trade union. ACFTU has not been directed towards contracted work and the adjustment of unequal power relations between a powerful employer and a powerless employee. Its basic rationale was that of a hierarchically organised political institution, which received its power from its interconnectedness with the state and fulfilled political, social and recreational functions at the grassroots. From the very beginning, industrial relations in socialist China have always been tripartite and striving for the general (production) interest of the country at the expense of workers' interests. Fourth, the Chinese welfare system was an early creation of the socialist state inspired by Leninist principles and Soviet practice. It was established under the condition of a young workforce and full-employment and became an important element in China's industrialisation strategy. Comprehensive welfare coverage, however, was strictly limited to centrally planned state employment in urban work units (SOE and government offices) and urban state workers. Although its development has not been continuous since the early 1950s, the welfare system of the SLR reproduced the dual-track structure of the society at large and reinforced the divide already produced by the hukou.

The state assumed the financing of urban welfare (e.g., old age, health, work insurance) and subsidies for housing and food. The system provided a cradle-to-grave security for a young 
and immobile population, albeit on a modest level. These benefits supplemented the low wages of state workers. The system excluded the rural population from state benefits and referred people in the countryside to community self-reliance or family support. People lacking working ability and a family to support them were granted basic help.

The strong connection between danwei membership and social security entitlement created the well-known inclusion of the urban population into the society and the SNWP in the absence of any alternatives. The functional logic of the interplay between the two institutions of control and social welfare has been inspired by the political goal of the formation of a working class as the system's political avant-garde. Despite political rhetoric, equality in urban employment has not been absolute (Ahmad and Hussain 1991: 279f.). In addition to the rural-urban divide, Selden and You point to the fact that the availability of benefits for urbanites depended on 'four primary axes' or classifications, i.e., (1) state or collective unit, (2) large or medium/small unit, (3) cadre rank or worker/apprentice and (4) regular or temporary/contract worker (Selden and You 1997: 1659). The logic behind the division in welfare access is clearly political, in line with the systems of central planning and property rights, as well as the socio-political control carried out by cadres and the labour force inside and outside the work plans.

Despite the state monopoly over labour allocation and security provision, the SLR did not rule out the family as a fallback institution for care and social security. The Chinese social security system provided protection to a only a limited part of the urban population. In rural areas, the family remained the most important institution; and, in times of hardship, few forms of collective help and hardly any state assistance could be expected. But even in the cities, those left outside the labour-based (or danwei) provision of social security could not cover individual risks and shocks on the market. For those individuals, family and kinship networks served as a fallback system of security as well. Traditional values were called upon, based on traditional 'filial piety', kinship reciprocity and family law. In spite of political changes, even during the Cultural Revolution, the strength of generational relations, with practices such as old age support and care by family members, has been upheld as a valuable Chinese tradition.

Fifth, immediately after attaining power, the CCP intended to reduce the power of clans. To this end, it promoted a radical change in the role of families, kinship structures and women. A socialist marriage law was enacted as early as 1950. The law was based on socialist ideas and designed to overcome the existing social supremacy of men over women and the disregard of children's interests (Johnson 1983: 235). In accordance with socialist values, a new gender concept was also promulgated. This concept advocated that women should no longer be kept secluded and dependent on their husbands and parents in-law, but should 
achieve self-determination through participation in gainful labour. Women were also supposed to become key actors in production. Changes in the gender concept peaked during the 1960s, when women were chosen as model workers and 'iron girl brigades' symbolised the future of Chinese socialism (Hanser 2005).

The policy had a profound impact on the traditional family, kinship and gender order. Not only did the political and ideological propaganda have an effect on gender values and norms, but education, work place and job allocation, the organisation of production and social security all helped women to overcome their inferior status in the family and society. New concepts related to family and gender resulted in a dual earner pattern and enabled women to participate in the labour process. Day care and schooling for children, as well as a modest financial independence (pensions) of older parents was assured. On the other hand, women's inclusion into the workforce did not put an end to gender discrimination. Even though planned allocation did not officially differentiate between men and women, the majority of women worked in low ranking, poorly remunerated positions and the SLR remained biased with respect to gender.

Family, kinship and gender order have been interlinked with other institutions, demonstrating, in some cases, contradictory effects. The dual earner concept has been successfully connected to the institutions of population control via work units and the production concept which enabled low wage levels. However, the overall economic situation and policies counteracted the original intentions. The housing shortage and migration control reinforced strong family relations and traditional patterns of co-residence, patrilineal structures in geriatric care and the persistence of son preference.

Sixth, the value of education is deeply rooted in the Chinese culture as an element of human civilization and a type of advancement in bureaucratic status. Industrialisation and modernisation in pre-communist and communist China altered the goals and the structure of the educational system. General education, along with vocational and professional training, became an important institution related to the Chinese labour regime before and after the Revolution. The Chinese educational system developed structural similarities with corresponding systems in industrialised countries due to various external (e.g., pre-communist American and Russian communist) influences. Yet frequent explicit political interference, especially during the Cultural Revolution, destroyed the very foundations of the system.

Pre-reform education in China has also been crucial to the Party's ideological foundations and policy. Deng and Treiman point to three governing criteria: academic performance, family class origin and student loyalty (Deng and Treiman 1997: 394), marking a break with the criterion of performance during the Cultural Revolution. Education as a whole aimed at comprehensive social integration, the diffusion of basic education to rural and urban areas 
(e.g., literacy, inclusion of women), creating political loyalty and preparing the younger generation for a productive work life (according to the socialist model worker). Mass education programs via state intervention stressed the creation of political consciousness as their primary goal; but, in doing so, they damaged the educational system by deteriorating its standards of quality and its contribution to economic growth. Educational policy transmitted basic socialist values such as equality, e.g. the detachment of educational chances from parents' socio-economic and educational status, or the superiority of manual over theoretical work (Hayhoe 1992; Shirk 1981). These values had a significant and enduring impact on workers' aspiration and satisfaction as well as on work performance.

The pre-reform educational system has been closely connected to the production sector. Strong weight has been accorded to primary education and training for manual work. Technical training for those entering the work force, having been allocated by state labour bureaux, was provided in large part by the enterprises themselves. It was primarily on-the-job training and served to meet the specific needs of a particular enterprise and even one particular task. For the overwhelming part of the workforce, the educational system did not provide individual marketable qualifications in the form of transferable skills. This type of training proved to be an additional and important source of workers' immobility, at least for the part of the workforce with lower and middle level training.

Secondary and tertiary education found itself even more at the mercy of political waves. Universities were shut down in 1966; qualified young people were sent down to the villages at the end of the 1970s, and a so-called 'lost generation' entered the workforce due to the educational campaigns during the Cultural Revolution and anti-meritocratic tendencies favouring students of 'good class background' (workers, peasants, pre-communist revolutionaries). All this resulted in the lack of a medium to highly qualified stratum of experts in the workforce. Nevertheless, no considerable gap between the demand side of production and the qualification level of the workforce opened up at the outset of the economic reforms, because the production regime, work organisation and the technical level of production remained low at that time.

In brief, the above-mentioned set of institutions formed the highly inclusive labour regime of the socialist period, producing full employment and comprehensive welfare, high rates of female employment participation based on changes in the family and gender order, but also due to the strict rural-urban divide and authoritarian dependency of the workforce. The SLR clearly favoured the urban working class. Particularly members of state-owned work units exchanged individual immobility for risk reduction and social benefits. The SLR represented a trade-off between the goals of socio-political control and state-led industrialisation in the urban regions, based on unfavourable terms of trade between the countryside and cities and 
the extraction of resources from the rural areas. Among other factors, the SLR relied on the collectivisation of land and local communal institutions in the rural areas, institutions that drew the rural population into farm work in the absence of other alternatives or, in other words, chained the farmers to the land.

The deep and nearly insurmountable rural-urban divide shielded urbanites from rural labour competition. But this 'invisible Great Wall' (Knight and Song 2005) has been only one prominent feature of the segmented pre-reform labour regime. A second characteristic can be identified in the institution of the Chinese 'work unit' (danwei). Employment in state and large collective enterprises was essential to ensure a regular urban SNWP, symbolised by the famous Iron Rice Bowl. Employers and employees were not contractors in the Western sense of a labour relation and, as such, labour associations or free trade unions were deemed unnecessary. Danwei took on the character of so-called 'mini welfare-states' or 'small societies' that did not require a market for goods and services. Managers and cadres assumed the responsibility for and control over their dependent workers in the realms of both work and private life. Workers under the regime of the SNWP enjoyed comprehensive security at the cost of flexibility, privacy and individual decision-making. Chinese urban workers were bound into an internal, firm-centred labour regime to a much higher degree than even their colleagues in other socialist countries.

The SLR and the SNWP have been backed up by the whole set of institutions and their particular logic. Each institution of the set incorporated traditional cultural elements, as well as new, time-related aspects of the socialist period. Marxist ideology and work policy challenged cultural traditions on some points (e.g., emphasis on manual labour) and reconciled them at others (e.g., hierarchy and segmentation). The interrelated institutions are not free from contradictions and conflicting goals, as has been shown in the example of family, kinship and gender order.

The present transition period exercises an intensive pressure on all the institutions to change their principles and to rearrange them in order to meet the necessities of the time. Following our basic assumptions from the beginning of this text, these changes will be path-dependent in the sense of including former and present elements in a contingent manner.

\section{The Emerging 'Socialist' Market Labour Regime (SMLR)}

The fundamental changes of the SLR during the reform period are obvious to every Chinese and foreign observer. A labour market emerged and contracted labour spread. We will not recall here the various steps and measures undertaken by Chinese politicians. This has al- 
ready been done elsewhere by several Chinese (Yang 2002; He 2003; Cai et al. 2005) and western researchers (Knight and Song 2005), as well as ourselves (Hebel 2005; Hebel and Schucher 1999; Hebel and Schucher forthcoming). Instead, we will attempt to elucidate the institutional changes which affected and modified the SLR. We will argue for the presence of both continuity (as regards a particular regime trajectory) and discontinuity in this regime due to various endogenous and exogenous factors, such as privatisation, globalisation and WTO membership.

For most observers, the rapidity with which the SNWP has been dismantled in the past two decades verges on the unbelievable and was possibly only been overtaken by transformation in Easter Europe. The most decisive step in this process of regime change has been the state's withdrawal from labour allocation and employment. This step corresponds with the transition towards a 'socialist' market economy and includes the restructuring of the public sector and admittance of private economic activities. In the public sector the former lifelong job tenure and work unit membership has been challenged; in the private sector contracted work is now the rule. An informal sector of employment - still within the public and private industry - has also come into being, meanwhile absorbing a considerable part of the work force. Self-employment has become an important option for the younger generation or dismissed workforce and, in particular, the rural population. Mobility has been on the rise since the early 90s, encompassing processes of regional migration (rural-rural, rural-urban etc.) and job mobility (up- and downward mobility). The most important instrument of population control, the hukou system, has lost its overwhelming importance.

The new 'socialist' market labour regime (designated SMLR) is characterised by a shrinking public sector accompanied by an expanding private sector. A decline in formal and gains in informal work, along with the expansion of self-employment at the expense of dependent work round out the picture. A progression from agricultural to industrial and service work has also taken place (Lu et al. 2002). Increases in mobility and flexibility of the workforce can be attributed to the restructuring of the public sector and the expansion of the private sector (Hebel and Schucher 2006).

In the following section we will elaborate on the institutions we have chosen for our analysis and the changes they have undergone. The most remarkable among the latter include the retreat of state intervention, the expanding role of markets and alterations to the institution of family and gender roles. The changes can be deciphered as not only being phat or state dependent (to use Page's terms), but also co-authored by their internal logic, the rationale of corresponding institutions and the sequence of their implementation. This raises the question of a new equilibrium and coherence between different institutions. Throughout the fol- 
lowing discussion it should be kept in mind that these institutions are interrelated and exert contradictory influences on the labour regime.

\subsection{Socio-political Control}

The socio-political control of the population was based primarily on the hukou system, which stratified the population in urban and rural segments and gave rise to either danwei access or membership in rural collectives. This system of socio-political control has been dismantled in the course of economic and political reforms, even though the core regulations of the hukou system still remain intact. Two major rationales appear to drive the reform of the hukou system, the first being an economic logic and the second involving concerns about social stability. On the one hand, population immobility has caused economic irrationalities such as low labour efficiency, market segmentation, rural underemployment and slowing urbanisation. On the other hand, uneven regional development and a widening income gap between farmers and workers has led decision-makers to the conclusion that the massive transfer of rural workers to the cities seems to be the most promising way to increase rural incomes and facilitate the development of a unified labour market.

The first steps in the reform policy have been the dissolution of rural communes and the introduction of the Household Responsibility System, together with the rise in state purchasing prices and transformation of farm surplus into industrial investments (Pei 2005). Although the hukou has been upheld as an instrument of migration control, the rural population was released from the ties of agricultural labour and local bonding. Significant shifts in rural labour occurred with the rise of dependent industrial employment in collective and private town-and-village enterprises (TVE) and an increase in self-employment. Migration of rural surplus labour to urban areas increased and rural workers entered the urban labour market. Since the mid 1990s the political control of the rural population exercised by hukou registration has been officially relaxed and former boundaries ignored. On its $16^{\text {th }}$ Party Congress in 2002, the CCP proclaimed its intention to abolish the system; in October 2005, plans were published to begin with 11 of the 23 provinces in 2006 (China aktuell, 2005/6: 64f.).

The second significant step of the reform policy has been the restructuring of the SOE, the dissolution of the danwei by 'socialising' its social functions, and the gradual deregulation of the SNWP. In order to enable reallocation and facilitate the flexibility of labour relations, in 1986 the labour ministry announced the official introduction of labour contracts in the public sector. Short-term labour contracts and dismissals upon contract expiration - characteristics of the emerging group of contract (system) workers (hetongzhigong) - launched a process of dissolution of the SNWP. The first addressees of work contracts in state-owned enterprises, 
however, were only the new entrants. Even though the national labour law of 1995 pushed the implementation of obligatory contracts for all categories of firms and labourers, the number of labour contract workers rose quite slowly. Only by the end of the 1990s could the inclusion of nearly all workers in urban state and collectively owned enterprises into contract relations be attained.

The implementation of the labour contract system shows strong signs of path dependence. Although the state initiated the changes with its usual experimental introduction in SOEs, it also continued to privilege the established working class, mainly in fear of stirring up political and social unrest. Later, the coverage of the contract regulations was gradually expanded to other groups of workers, including the core of state employees. Until today, however, the implementation of the regulations remains limited. On the one hand, contrary to the wording of the labour law, rural migrants and the growing group of workers with atypical labour relations are still formally excluded. 'Atypical' includes all kinds of flexible (instead of permanent) employment and part-time (instead of full-time) employment. ${ }^{1}$ On the other hand, the actual compliance with the obligation to conclude contracts in private enterprises must be doubted when the lacking supervisory capacities of local governments are considered. In March 2006 the National People's Congress published a draft law on labour contracts that will be legally binding for all types of labour relations (Schucher 2006).

The same pattern holds true for the attempts to reduce the redundant work force in SOEs. Initial endeavours to improve the flexibility of labour relationships in these organisations (such as the program of 'labour optimisation' at the end of the 1980s) remained unsuccessful. Only since the mid 1990s did changes occur with the new concept of 'removal from posts' (xiagang), which allowed SOEs to lay off permanent workers. Xiagang workers do, nonetheless, experience special treatment: they remain affiliated to their work units and continue to receive basic remuneration. They are also given preferential treatment in reemployment centres. In the end, the ambiguous xiagang program turned out to be a method to protect SOE workers from regular unemployment, as well as a selection technique for unproductive 'privileged' workers to be released from work relations. Official announcements to phase out these practices and to integrate xiagang workers into normal unemployment procedures has not been realized so far.

A third step of reform has been the opening up of the private employment sector. Both formal and informal work under dependent work conditions and also self-employment have

1 In China, atypical employment is gaining ground. However, definitions remain vague and exact figures are almost not available. Even the Ministry of Labour and Social Security seems not to have a clear concept as it uses synonymously the terms 'temporary employment', 'informal employment' or 'flexible employment' to describe 'non-standard employment'. Consequently, figures vary between 50 and 70 million atypical jobs or even more. See Hebel and Schucher 2006. 
accelerated. The Chinese government, aware of the problems arising from transition and restructuring, responded with a 'Proactive Employment Policy'. Its principle is 'workers finding their own jobs, employment through market regulation and employment promoted by the government', as stated in the government's White Paper on employment (White Paper 2004b). The private employment sector has opened up an unexpected degree of job mobility and regional migration.

Factors such as the new leniency in the hukou system, the appearance of labour contracts, of greater mobility, and the disbanding of the danwei all contributed to the undermining of the former rationale of the SNWP. With that, a total rearrangement of all other institutions was required, witnessed in e.g., the call for a renewed welfare system, for new labour relations that fit with contracted work and demands for more highly qualified work force. This ongoing transition must be brought in line with changes in the production regime, i.e., changes in the industrial structure, property rights, organization of production and technical standards.

\subsection{The Production Regime}

Changes in the state's industrialisation strategy and planning system are certainly extremely important to the production regime. Pre-reform China followed a state-led policy of forced industrialisation and created a typical dual economy. The system of central planning comprised capital and labour flows. Investments of farm surplus were directed into the development of the state-owned heavy industry, neglecting light and service industries. Ruralurban financial transfers allowed the state to create und uphold its SNWP, supplementing the urbanites' low wage levels with a wide range of social security benefits and subsidies.

What Pei has termed a reverse flow of capital from the state to peasants ignited a series of changes in the production regime. This movement brought both capital and investment goods to the rural surplus labour and enabled the expansion of light industry (Pei 2005: 7, 20ff.). Chinese economic transition began with the rapid expansion in rural industrialisation (collective and/or private TVE) and in labour-intensive light industry. In addition, a considerable expansion of the previously neglected service sector in both rural and urban areas also took place.

The state was altered from an institution which prescribed the production organisation, prices, quantity and quality of goods and labour to one that defined and coordinated the legal and economic market framework. The reduction of state planning and public property on the one hand and an active legislation for the market economy (i.e., labour law, social security regulations) on the other can be seen as indicators for the new role of the state. Rural and urban economy developed their own market-driven dynamic, leading to considerable restructuring of the Chinese industry and its production regime. Moreover, a trend in politi- 
cal decentralisation occurred, which provided regional authorities with increased decisionmaking power in industrial policy, fiscal and labour regulation and legislation.

Changes in agriculture already occurred during the early 1980s. A quantitative expansion in employment took place with the large-scale reallocation of resources. Rural industrialisation mushroomed due to a predominantly labour-intensive type of production and a considerable portion of the rural surplus work force was absorbed by these new industries. As the rigidity of the hukou declined, farmers moved to urban areas or export processing zones in search of service and industrial jobs. Migrants became a mobile reserve of cheap labour in the cities.

Alongside macro-economic shifts in the industrial structure, the (urban) state sector began to introduce incremental changes in its production regime. By the mid 1980s, the state conceded enterprises the rights of management and economic responsibility. Greater economic freedom of action enhanced new business and labour strategies within the public sector (Hebel 1997). SOE have been 'restructured' in a number of ways that deeply influence the labour regime at large. This can be attributed to a number of changes: 1. A turnaround in personnel policy took place. Labour redundancies were reduced by different strategies (including increased unemployment) and labour entries were lowered and corresponded better with economic demand in number and quality of the workforce. 2. Work compensation increased, albeit for a reduced number of urban workers. Wage increases created a considerable urban demand for consumer goods and services, thus far neglected. 3. Labour mobility augmented according to individual aspirations or needs. 4. Technical and professional training became a prerequisite for employment and formal work contracts. The opening policy introduced new production technologies and created the demand for higher qualifications. 5. Comprehensive welfare provisions by the danwei were abandoned and a new and market related welfare system was established. 6. Although work contracts came into general use, work relations did not change significantly. Political control remains important at the grassroots level and the free representation of workers' interests continues to be suppressed. Nevertheless, the shift towards contracted labour has diminished the intermingling of workers' work and private spheres.

The production regime of the private sector is as heterogeneous as the sector itself. Property rights are manifold. The private sector comprises the whole range of production techniques, such as labour-intensive services and production on an inferior technical level, Tayloristic assembly line production of the early industrial period as well as high tech, capital-intensive and labour-saving production. Thus, the demand for labour qualification is rather diverse. Labour relations in the private sector are based on formal or informal contracts and, in the wide sector of family-based enterprises, on kinship relations. In brief, the private sector es- 
tablished a completely new and comprehensive mode of labour management including work and authority relations, work control in the labour process, labour contracts and remuneration and social security schemes.

An external labour market emerged covering the public and private sector. This emergence went hand in hand with the erosion of the SNWP. The current Chinese production regime transgresses older constituent segments defined by property, size and location of public enterprises. Globalisation and privatisation now shape its characteristics and have transformed its basic rationale from a state-led matter to an economic endeavour. The impact of production organisation on the labour regime results in the absorption of market elements and, with what is known as a 'gradualist strategy', combines a mix of traditional, socialist and market elements.

\subsection{Industrial Relations}

Labour relations in China during the period of the SLR have been determined by the monopoly of a single legal union organization with branches in provinces, industrial sectors and enterprises (basic level trade union committee). The ACFTU formed a state-corporatist institution that contributed to the control of the industrial workforce or, in other words, a political transmission belt. Its dualistic role consisted of the implementation of state industrial policy, among other policies (e.g., family policy) and the protection of workers' welfare interests. As workers were considered 'masters of the enterprise', the representation of their job interests was deemed unnecessary. A paternalist labour regime was installed (Chen 2003: 1009).

The dismantling of the SNWP, changes in property rights and the emergence of a private sector all served to challenge the socialist understanding of representation. Interests of the state, labour and management proved to be divergent as labour conflicts spread. Thus, the need for worker representation supported by a revised union concept became more apparent. In 1992 a new Trade Union Law was enacted, followed by a Labour Law in 1995 and an amended Trade Union Law in 2001 (Geffken 2003a, b). In addition to this core legislation, numerous central and local regulations on employment have also been approved. Nevertheless, no fundamental change has occurred and, as Chen puts it, 'organisationally, unions remain subjugated to state dominance and their cadres are still state nomenklatura' (Chen 2003: 1012).

Although, as stated in Art. 6, legal provisions exist as regards the basic duty and function of trade unions to 'safeguard the legitimate right and interests of workers and staff members', no fundamental turnaround in union policy may be observed. The 2001 version of the Trade Union Law still emphasizes that the unions should educate and mobilize workers to fulfil 
their production tasks and other work (Art. 5 and 7). In cases of violations in regulations and of work disputes, the union is called on to mediate conflicts, protect the property of the enterprise, help restore the normal order of production and safeguard peace. The crucial point is that the power of the unions does not stem from the organized labour force, but rather the state. The ACFTU continues to be an institution which retains much of its power from the state and the new Trade Union Law outlaws any freedom of association or the right to strike. Conflicts are preferred to be settled by mediation rather than by courts or even collective action.

Nevertheless, with the transition of the economic structure the Labour and Trade Union Laws introduced some new elements. Labour laws apply to the workforce at large and unions are concerned with all types of employers and employees. The extension of labour relations beyond the state sector is an important adaptation to the new SMLR. In theory, migrant labourers and workers in private enterprises are also covered by the labour regulations. Unions must be set up in all enterprises, institutions or government departments with a minimum of 25 employees (Art. 10), regardless of their type of property. Yet, implementation is lagging and only recently have trade unions begun to admit rural migrants.

In response to the replacement of the administrative regulation of labour relations and the increased need for worker security in matters of wage settling, maintaining work conditions and labour safety etc., the institution of collective contracts was created, in effect since 1995. Through joint consultations collective contracts are supposed to be reached between the representatives of the enterprise management and its employees, i.e. the trade unions. The purpose of collective contracts is to provide a framework for individual work contracts. They are at best an instrument to monitor the enforcement of the Labour Law (Clarke et al. 2004). Under the influence of the ILO, tripartite consultations between representatives of the state, employers and employees have been established on the national level in 2001. Their main purpose is to resolve labour conflicts; but, like collective consultations in the enterprises, they contain a marked flaw in their negligence of the most important conflicts, those regarding wages (Clarke and Lee o.J. [2002]).

In sum, the new regulations and laws implemented to this point are in large part merely modifications to the traditional system of industrial relations. As an integral part of the political system and the enterprises' management system, unions are called upon to contribute to stabilisation of production and national development. In the wake of the astonishing degree of decentralisation of political and economic power and the emergence of a Chinese version of the Asian developmental state with manifold regional and local initiatives, unions are pressed to support local interests with regard to industrialisation, even at the workers' 
expense. In view of their specific role, the unions find little solid ground in the expanding sector of non-state enterprises, which could easily lead to their future marginalization.

\subsection{The Welfare Regime}

Transition in China and the need to facilitate market economy reforms and stimulate economic growth has brought enormous pressure on the Chinese welfare system for a number of reasons: (1) The basic conditions of a young working population and full employment eroded. China is currently witnessing the aging of its population, along with labour redundancy and unemployment. (2) Increases in the urban working population outside of the public sector have challenged the exclusive and politically legitimised distribution of welfare to a small part of China's working population. (3) The strong attachment of social security to work units and the administration of the system by local trade unions became obsolete with the restructuring of SOE and rising inter-enterprise mobility. (4) The withdrawal of the state in labour planning and welfare funding required the coverage of a larger share of workers and new ways of funding. (5) Migration and the expansion of the private sector in urban areas spawned the need for a new welfare concept to include the workforce at large. (6) Demands for a unified national labour market, as well as growing concerns about social stability, present the challenge of new welfare solutions for rural areas. (7) The new welfare regime must meet the challenges of the changing production regime and new educational demands, in addition to responding to changes in the family, kinship and gender order and increased migration.

Although institutional modifications to the welfare regime are still underway, notable changes have already taken place. The welfare responsibilities and the relative weight of work units, their employees, and the government in providing social benefits have been redefined. The financing of most benefits has been shifted away from work units to general taxes paid by individuals. In order to respond to a more mobile workforce, a wider riskpooling scheme across firms has been adopted and individual worker accounts have been established. Employees have assumed a much greater responsibility in financing social welfare, both directly and indirectly. Especially local governments have taken a larger role in welfare provisions. To avoid social unrest, a safety net for the urban poor has been established via public assistance programs.

The new system - as designated by the 2004 White Paper on Social Security (White Paper 2004a) - is comprised of five tracks of social security (Old-Age, Unemployment, Medical, Work-related Injuries and Maternity Insurance) as well as social welfare (for the elderly, children and disabled people), a special care and placement system, social relief (Guarantee of the Minimum Standard of Living for Urban Residents, Natural Disaster Relief, Relief for 
Urban Vagrants and Beggars and Social Mutual Help), and housing security (System of Publicly Accumulated Housing Funds, Generally Affordable and Functional Housing System and Low-Rent Housing System).

Empirical research has shown a transition in the urban social welfare system from its original massive scope to a more residual role with regard to its provisions. Despite increases in the real value of total social benefits, their contribution to final household income has actually decreased significantly. Pensions, health, and education programmes are increasingly based on individual contributions (Gao 2006). The government states that 'under the influence of China's traditional culture, there is a time-honoured tradition of provision by the family, security coming from self-reliance and help from the clan' (White Paper 2004a).

Due to the government's retreat from welfare funding, e.g., health services, delivery is deteriorating, especially in the rural areas. Furthermore, the cost increases linked to the privatisation of the health care system result in the exposure of poor households to the risks of either non-use or financial debt. An expansion of health insurance coverage would be an obvious response to this challenge. But, so far, provisions in this area in China have been on the decline in recent years. Moreover, the unemployment, pension and health insurance systems are facing serious financial problems due to the deteriorating ratio between labourers and beneficiaries. Given these conditions and no better prospects in sight, China is confronted with serious challenges to the successful establishment of a national unified welfare program.

Despite the general levelling of the rural-urban divide, the current system still maintains this difference. Welfare reforms, however, also demonstrate the continuing influence of the danwei and pre-reform urban-rural segmentation. The reform of pensions and health insurance, as well as the introduction of unemployment insurance, aimed to free workers from danwei dependency and to open up social mobility between enterprises and jobs. Nevertheless, the reform followed the lines of the planning system. Coverage is restricted to urban residence and to formal employment. Rural welfare institutions are still in their embryonic phases. Consequently, coverage continues to be limited and locally divergent social welfare provisions have become an additional hurdle to cross-regional mobility (Hebel and Schucher 2004). The legacy of traditional arrangements also surfaces in cases such as when enterprises on the verge of bankruptcy must submit a plan to detailing the allocation of welfare funds to their employees.

\subsection{Family, Kinship and Gender Order}

At first glance, family and kinship organisation, as well as gender order, might not seem closely connected to the new SMLR. However, family and gender concepts were crucial 
elements in the socialist ideology, and they continue to interact with other institutions. The gender debate underscores a close relatedness of gender culture, gender order and gender relations to the work setting and, moreover, to social stratification (Pfau-Effinger 1997). As mentioned above, the SLR advocated sexual equality: The true socialist model worker was an experienced blue-collar worker, male or female. Although gender equality has been politically enforced, inequality persisted. Women continued to predominantly work in the light industry and in small enterprises; consequently, women's wages remained lower on average.

During the recent transition, considerable changes in family and gender concepts took place. With the retreat in state labour allocation, restructuring of the public sector and private job procurement, new gender values have been increasingly emphasized. Hanser (2005: 582) characterises the change in the gender culture as a 'shift from the iron rice bowl to the rice bowl of youth'. Conversely, the new gender order structures the labour regime: middle aged (experienced) women workers in the public sector are the first to be dismissed or sent into early retirement; the private sector looks for young, sophisticated female workers or for cheap and unqualified manual labourers in the assembly or textile industries.

In her qualitative research on three types of retail shops, Hansen describes how the social value of middle-aged experienced working class women decreased in the state productive sector or in service-related work. On the one hand, modern service industries and trades favour the 'rice bowl of youth' (qingchunfan), i.e., young women embody modernity through their specific performance of contemporary femininity. On the other hand, rural and migrant women employed in assembly work or textile production are faced with a devaluation of their manual labour. This stems from stigmatising perceptions which assign these women an inferior personal value (suzhi) and regard them as having unrefined culture, thus making them an easy object of exploitation (Anagnost 2004). Basic level unions either do not have the weight to intervene on their behalf or refrain from action in many cases.

Labour takes on another meaning for young women in light and service industries. The institutionalisation of this more modern work for young women in the SMLR eroded older values and linked them to inefficiency and backwardness. Young women's work often represents no more than a biographical episode, and fails to offer longer term perspectives. The gender culture incorporated in the present pathway of Chinese modernisation is reminiscent of Japanese female work patterns: work careers are short and end in marriage. The dual earner model is still in place and officially promoted. Nevertheless, the economic transition brought about a number of de facto changes in concepts of family and kinship and produced, once again, a number of contradictory effects. The one child population policy had a deep impact on the family structure, leading to fewer horizontal kinship relations 
while the number of vertical relatives increased. Longevity became an important factor for the emergence of what can be called a 'beanpole structure' in families. In rural areas with almost no social security system, an aging population and privatised services, families are the only source of support in periods of hardship. The need for care and support emphasizes strong family relations and co-residence. Yet, out-migration counteracts this trend. Rural migrants are less likely to co-reside with their parents, although remittances may act as a substitute for personal support. In the long run, strong ties may be dissolved due to these distances (Cai 2003).

Residence in the cities changed with the intensified construction of new housing areas and apartments. On the one hand, the more mobile younger population does not need to share a residence with its parents upon marriage. On the other hand, increased unemployment fosters co-residence with relatives and enhances traditional family values. In younger dual earner households, childcare is a key problem that is often solved with the help of grandparents. In many cases, the low level of pensions in an underdeveloped social security system is compensated by the financial and practical support of the children. Thus, co-residence with adult children in urban China remains high, though not necessarily a sign of traditional values (Logan et al. 1998). Non-normative co-residence, i.e., with the wife's parents, is on the rise and will certainly expand when the children of one-child families come of age and marry (Pimentel and Liu 2004).

The new SMLR opens up new opportunities and investments in education gain in importance. In cases of scarce familial resources, these investments are preferentially given to sons. The new employment structure strengthens the influence of prevailing cultural norms and favours sons over daughters.

Recent changes in the family, kinship and gender order must also be looked at from the perspective of their relationship to different social strata. Social stratification produced unequal conditions for income generation and housing as well as for social security, childcare and educational investments. In practice, the family order, intergenerational relations, coresidence of parents and married children and the role of women vary with the social position of families (Zhang 2004; Logan et al. 1999). Furthermore, the type of employment pursued by the family members influences the family order. Family businesses or selfemployment, e.g., enhance not only the cooperation of family members in economic activities, but also add an element of pressure to the familial arrangement.

In sum, the Chinese family, kinship and gender order exhibits little similarity with family life in the West. The institution is strongly interrelated with other institutions and there is no clear tendency marking a transition from traditional to so-called modern values. The order has a particular history and present changes are shaped by prior arrangements. 


\subsection{The Educational System}

The pre-reform educational and training system turned out, in the end, to immobilise the workforce and hamper economic development. Faced with the changes in the production regime, the educational system proved to be insufficient in relation to the quantitative and qualitative demands for an adequate labour force. Ten percent of the Chinese labour force has no schooling and one third only primary school (1999). College or university graduates make up only $3.8 \%$ of the labour force (Lu et al. 2002: 29). The public and private economic sectors, both urban and rural, are in need of manpower with managerial and technical skills capable of meeting the demands presented by technical and economic renewal. The need for human capital pertains to all educational levels: besides higher qualifications, there is a considerable demand for a technically trained mid-level workforce. Moreover, a huge demand for lesser skilled labour in the processing, assembling and construction industries will persist in the near future. Training is not only a question of technical skills, but also a matter of the achievement of work attitudes. From the Western point of view, attitudes towards work and performance under the SLR and SNWP were often reluctant and combined with a lack of personal responsibility.

The changes of the production regime induced a shift towards a modern education system, which has now been underway for over a decade. China is currently striving for an expanded and highly competitive national system with international connections. Quality control is stipulated and certificates are to be officially accredited. In line with these aims, the main focus has been placed on the tertiary sector; admission rates have expanded significantly since the end of the 1990s. Despite progressing reforms, the educational system has not been able to overcome its quantitative imbalances; higher level education still constitutes a bottleneck on the way to a knowledge society.

The 'mismatch' between the educational system and the production regime became especially obvious as urgently needed qualified high school graduates experienced difficulties finding jobs in large numbers. Chinese education politicians and scientists sought to explain this phenomenon by citing the reasons mainly in the prevalence of theory-biased curricula over practical knowledge, the reluctance of graduates to leave the bigger cities for jobs, and insufficient job placement information.

An additional flaw in the educational system can be localised in the traditional neglect of vocational training. Despite considerable efforts, vocational training is still regarded as inferior to general education. This view is enforced by systemic problems that make secondary vocational training a dead-end street without possibilities to move on to higher education.

While heavily financing high quality education and research, the central government - in keeping with its general policy - has withdrawn much of its monetary support from public 
Table 1: Overview of the Pre-reform and Present Chinese Labour Regime Types

\begin{tabular}{|c|c|c|}
\hline & $\begin{array}{c}\text { (Pre-reform) SLR } \\
\text { (Socialist Labour Regime) }\end{array}$ & $\begin{array}{c}\text { (Present) SMLR } \\
\text { ('Socialist' Market Labour Regime) }\end{array}$ \\
\hline $\begin{array}{l}\text { Political } \\
\text { control } \\
\text { regime }\end{array}$ & $\begin{array}{l}\text { Hukou-based residence control } \\
\text { and danwei-based social controls } \\
\text { Rural collective commune system }\end{array}$ & $\begin{array}{l}\text { Diminishing importance of hukou and danwei } \\
\text { Abolishment of the rural collective organisations }\end{array}$ \\
\hline $\begin{array}{l}\text { Production } \\
\text { regime }\end{array}$ & $\begin{array}{l}\text { State-led industrialisation and } \\
\text { monopoly of the public sector } \\
\text { Labour-intensive production } \\
\text { processes } \\
\text { Central industrial and labour } \\
\text { planning, planned wage setting } \\
\text { Labour-consuming enterprise } \\
\text { policies (enlargement of the } \\
\text { workforce) } \\
\text { Permanent and full-time } \\
\text { employment } \\
\text { Rigid rural-urban divide }\end{array}$ & $\begin{array}{l}\text { Market-led industrialisation and de-monopolisation } \\
\text { of state labour (self-employment, private business, } \\
\text { foreign-owned companies) } \\
\text { Productivity-oriented production } \\
\text { Demand-driven job placement, market exchange on } \\
\text { wages and the price of labour, labour mobility } \\
\text { Efficiency in labour use: quantity and quality of } \\
\text { recruited employees and workers } \\
\text { Contracted labour, atypical and precarious employ- } \\
\text { ment, unemployment } \\
\text { Migration }\end{array}$ \\
\hline $\begin{array}{l}\text { Industrial } \\
\text { relations }\end{array}$ & $\begin{array}{l}\text { Trade unions as political } \\
\text { transmission belt and social } \\
\text { institutions }\end{array}$ & $\begin{array}{l}\text { Trade unions with traditional functions (political, } \\
\text { social) lose in importance } \\
\text { Embryonic features of (politically independent) } \\
\text { workplace representation }\end{array}$ \\
\hline $\begin{array}{l}\text { Welfare } \\
\text { regime }\end{array}$ & $\begin{array}{l}\text { Work unit-related welfare system } \\
\text { Collective rural support }\end{array}$ & $\begin{array}{l}\text { New (national) welfare system, detached from the } \\
\text { enterprise administration, with individual accounts; } \\
\text { private insurances } \\
\text { Monetarization of fringe benefits } \\
\text { Family as a (fallback) security net }\end{array}$ \\
\hline $\begin{array}{l}\text { Family } \\
\text { order }\end{array}$ & $\begin{array}{l}\text { Dual earner family model } \\
\text { Female work participation }\end{array}$ & $\begin{array}{l}\text { Dual earner family model } \\
\text { Female work participation } \\
\text { One-child policy }\end{array}$ \\
\hline $\begin{array}{l}\text { Education } \\
\text { system }\end{array}$ & $\begin{array}{l}\text { Enterprise-specific and job } \\
\text { preparatory training }\end{array}$ & $\begin{array}{l}\text { Qualification as a personal property for market } \\
\text { exchange } \\
\text { National system of professional training (accredita- } \\
\text { tion of certificates, quality control) } \\
\text { Expansion of education system (knowledge-based } \\
\text { economy) }\end{array}$ \\
\hline
\end{tabular}


education. Financial decentralisation rendered public education more expensive and opened up a private market for professional and technical training. Decentralisation also increased educational inequality, already identified as one of the key problems facing the Chinese educational system following twenty years of reform. Rural areas in particular have suffered from this policy. Although farmers invest in the education of their children as well, the reliance of (primary and secondary) education on local revenues and private savings affects the extent and quality of rural education. The average spending of the urban population on education is higher than that of the rural population and this difference has increased over the course in time (Willmann and Schucher 2005).

China's politicians view the country as being on its way towards a knowledge society. To achieve this goal, however, it is in need of a completely different type of worker than the one promoted by the ideal of the socialist model worker. Occupational aspirations, biographies and performance are changing with the emergence of more individualist conceptions of productive and private lives. The value change in the knowledge society will also shape the institution of family and gender order, with increasing levels of individualism, particularly on the part of women. Yet, it remains to be seen whether the gendered labour market will open up new opportunities for women or exclude them on account of unequal family investments in education and increasing unemployment, as mentioned by Jacka (1990). The proportion of female workers in the private sector has decreased in recent years ( $\mathrm{Lu}$ et al. 2002: 31). Women have experienced a degradation of their experience and their contribution to productive work.

Summarising, we may record a substantial and impressive restructuring of the Chinese labour regime in line with the transition towards a 'socialist' market economy. Table 1 gives an overview of the main regime changes.

The above-mentioned institutions no longer support the old regime. Neither can they be said, however, to embody a coherent new regime. Seeking to combine social stability, for instance a highly inclusive labour regime with a highly productive economy, the Chinese reformers adhered to the strategy of economic and social dualism for about 20 years. Only recently has the party-state declared itself in favour of a unified labour market (White Paper 2004b); institutional heterogeneity is, nevertheless, still prevalent:

- Socio-political control of the Chinese population has been slackened, at least with respect to the dismantling of the hukou and danwei systems. The 'invisible Great Wall' between the countryside and cities has become more permeable. Rural migrants to the cities, however, still remain 'second-class citizens' and face discriminatory treatment in a number of ways. The majority of migrants are only marginally integrated, employed in inferior, poorly remunerated and insecure jobs on the urban labour market. Authoritarian 
dependency of the population has been ruled out as an integrating mechanism. A new basis for societal cohesion has yet to be developed.

- The production regime has changed in various respects. Not only did the abolishment of central planning reverse the conditions of economic activities and 'soft budget constraints', but rural industrialisation, an emerging service sector, SOE restructuring, privatisation etc., all generated new types of gainful labour, new work relations and management styles. Production is now based on a wide range of different technology levels, which has the effect of placing different demands on labour. Work control, incentives and payment have become crucial elements in labour organisation.

- The decrease of the state's role in labour allocation and employment gave way to a new type of dependent and contracted work. Despite the Chinese Labour and Trade Union Laws, only embryonic attempts of worker representation at different levels are currently being undertaken. The admittance of free trade unions is not on the reform agenda.

- The renewal of the welfare system has taken place in accordance with different goals: on the one hand, the new system has to comply with the entitlements of employees and workers under the old labour regime and, on the other hand, new guidelines have to be established to extend coverage to new workforce groups. Urban state- and collectivelyowned enterprises have 'socialised' their welfare functions. Flexibility of labour has been increased at the expense of social security. An enormous effort of system change under conditions of an aging population and the rural-urban gap will have to be undertaken.

- The Chinese family remains a backbone institution. Family policy in China is bifurcated: it worked (and still works) against a strong family influence, while simultaneously installing the family as a fallback position for people in need. A considerable portion of the Chinese labour force is left alone with the risks and shocks occurring during the course of an average lifetime and need to fall back on their family and kinship networks. The nuclear family, dual wage earning and a renewed gender order conflict with the new type of dependent work.

- The educational system and professional training have become more sophisticated and better adapted to general labour market demands. Nevertheless, a low return on higher educational investments can be observed as well as a mismatch between the offer and demand of qualifications.

The emergence of an SMLR is taking place in a moment as China is working to become a highly productive competitor in the global economy, with its aims set higher than achieving success in the sector of low-skill production. Up-to-date production and information technologies are being shifted into the countryside and transform production processes. As an emerging knowledge society, the country also requires a new type of employee: well edu- 
cated, skilled and flexible. On the other hand, the political leadership of the CCP needs social stability in order to maintain its power. These conflicting goals have to be reconciled in the new labour regime, which is no longer a socialist one; nor is it already based on a true labour market. The socialist institutions of danwei, SNWP, labour planning and allocation have eroded and this has given way to changes in the set of institutions as a whole. Processes of institution building, however, lag behind market developments.

\section{Conclusion: Insights from the Transition of a Labour Regime}

Our earlier exposition allows two different conclusions, first, a summary of empirical evidence on the SMLR and second, some brief insights regarding the refinement of the labour regime framework.

First, we are able to differentiate distinguishing characteristics of the former SLR and the present SMLR in a descriptive summary. Prima facie, we may also hypothesize that the SMLR differs from other varieties of transformation labour regimes in Central and Eastern Europe and that it bears little resemblance to labour regimes in Western market economies. Our choice of six institutions for description provides us with a picture of their corelatedness in the formative process of regime change.

The pre-reform SLR regime was marked by a relative consistency, disregarding the urbanrural divide. Urban labour was centrally planned and allocated, and unemployment was non-existent for the major part of the socialist period via administrative measures. Mobility was reduced to a marginal event, occurring in the case of administrative labour transfer. Labour planning and the SNWP corresponded with the state-led production regime and industrial relations, with the social security and educational systems and, finally, the family and gender order. The comprehensive labour participation of women complied with two goals: the excessive labour demand of state-owned enterprises and the politically induced emancipation of women. Low, but egalitarian wages corresponded with the socialist ideal of a proletarian society. Economic productivity was low and the economy required few specialised qualifications. This relative consistency did, however, have its price. The proclaimed socialist equality remained a chimera and the established SNWP was only possible at the expense of the rural population. Consumption levels had been extremely low, although basic needs of the urban population were met. Rural labour has been tethered to agriculture and the countryside. Poverty persisted in many rural counties of the socialist country. Despite strong population controls and the curtailment of individual freedom, political stability had been 
permanently challenged. And, what is more, the SLR relied heavily on the old family and kinship order that the socialist system had intended to alter.

During the reform era, the anticipated increases in economic productivity and living standards paved China's way into both a policy of opening up the country and one of fundamental restructuring of its basic social institutions. The Chinese economy had to be liberated from the constraints of the planned system and an immobile workforce. Symbolically, the label of a 'socialist market economy', propagated since 1992, stands for this transition process. Within the new context of liberalisation, industrialisation, technical modernisation and, last but not least, WTO membership and globalisation, the different institutions maintaining the SLR were gradually eroded.

The present Chinese SMLR is still characterised by its socialist past, having inherited a considerable inequality between different segments of labour: rural and urban areas, southeastern coastal and inner provinces, public/core sector of the economy and private/petty informal economy, as well as between cadres and workers, young and old, and male and female workers. Socialist equality has always been ideologically marked and has favoured the urban working class as the political avant-garde. High-flown privileges for the urban formal workers were challenged in the 90s, but this worker segment still receives special treatment. Nowadays, rural labourers experience greater economic freedom as strong limitations on non-farm activities and mobility are loosened, but they continue to be discriminated as second-class citizens. Farmers' rights to rural land use are often challenged (e.g., by land confiscation) and, as migrants to the cities, their rights as labour contractors are not respected. China's economic success story is heavily grounded on the abuse of young rural female workers in the assembly, textile and construction industries. Multiple characteristics of the quasi military organisation of the production process, including strict work regulations with little to no recreation time, combined with inhuman living conditions, are an inheritance of both early pre-socialist industrialisation and of socialist work in the second-class non-public sector. A lack of implementation of the labour law and failing compliance with existing rules on the one hand and economic growth prospects creating new jobs on the other hand work to stabilise the terrible conditions of formal and informal work. The absence of labour protection, rights of political association and the prohibition of free unions is still sustained by the continued prevalence of socialist ideology on the workers' position in society. This ideology is far removed from the real working conditions of the exploited workforce. As violations of labour standards persist, frequent and spontaneous worker and farmer protest remains the only outlet. These problems could even increase. Officially, the actual need in farm-related activities is exceeded by a count of 150 million rural labourers, who face a 
transfer to non-agricultural jobs. They represent an enormous reserve army ready to work on any terms, while urban unemployment is on the rise.

The SMLR relies heavily on the institution of family and kinship. Obviously, family relations and networks of origin support migration. For the overwhelming majority of the Chinese work force in rural and urban areas, reciprocal support in families has to substitute for insufficient social welfare. But even among the urban 'better offs', the family has to step in when family members experience periods of ill health or problems of old age. In addition, the privatisation of education causes a heavy financial burden to be placed on families and influences career chances and status attainment. The family as a source of welfare and support is deeply rooted in the Chinese culture and has always been an unquestioned duty for the young. As the socialist system did not rule out the role of family despite its anti-family propaganda, the SMLR is characterised by a long-term continuity of embeddedness in the institution of the family. Nevertheless, changes in work careers, local residence and more individualist biographies may alter the value of family reciprocity.

Secondly, the analysis of the Chinese labour regime leaves room for further conclusions on the regime framework. As has been mentioned in the introductory section, the particular features of a regime are formed by the interplay of different historically and nationally distinct institutions. In our description we made reference to five institutions highlighted in the literature and added a sixth. These institutions have to be reassessed as regards their appropriateness in view of their increasing or decreasing weight within the set. Institution building during the trajectory must also be taken into consideration. Path-dependence proves to be more than an evolution from one state to another; it is rather a sequentially determined process containing a constant revaluation of institutions. The course of changes, however, is not only determined by the aforementioned state. Further development is contingent and dependent upon externalities (e.g., policy, global influences). As the former basis of sociopolitical control and state planning was phased out, political legitimacy and social inclusion needed to be regenerated. The implementation of law came on the agenda to fill in the gap. Contracts and private property rights have to be secured, although this is still insufficiently done. In analytical terms it may be said that a considerable 'road juncture' has been taken place. China is not an example for an unplanned trodden path, but for a branching pathway, to use the words of Ebbinghaus. Political decisions opened the country up to the world economy and created space for increased individual choices and predominantly economic freedom.

The regime framework allows for an analysis of the feedbacks and bi-directional causalities between different institutions. As has been exemplified in the Chinese case, the institution of family compensates for insufficient welfare institutions in the society. No general blueprint 
exists on how these two institutions have to interact to serve the well-being of the population. Based on pre-communist cultural traditions, the family persisted despite political headwind. Family and kin compensate for a lacking welfare system, reduce labour costs and enable a high international competitiveness of Chinese products. Current contexts and past experience are influential factors defining individual behaviour. Related institutions shape and control ideas, beliefs and behaviour and, in a two-way causality, influence institutional choices. During the Chinese transition, the SNWP has been dismantled and trust in public welfare and the legitimacy of the political institutions were undermined. As institution building in the welfare sector was slow to follow, a negative political and economic outcome loomed up and the family proved to be a reliable fall back institution.

Although our perspective has been focussed on the labour regime as an ensemble of institutions at the macro level, the micro perspective has to be included systematically in further research. In general, a normal regime trajectory consists of permanent minor institutional changes and requires the necessary adaptations of the population to new challenges. In contrast to such a 'normal' development, periods of transition cause breakdowns in wellestablished institutions. This happened, e.g., in the former German Democratic Republic and is taking place currently in China. The simultaneous events of the breakdown of the SLR and the SNWP as well as the emergence of a market-dominated economy and labour market uprooted almost all the behavioural routines of the population. Work took on a new meaning; people were forced to respond to new challenges and to reorganize their future life careers. Mechanisms of self-reinforcement under changing conditions, e.g., political control, processes of internalisation of norms and stratification, are a starting point for research. The relationship between an established labour regime and actors that form and reshape the institutions through their choices shaped by largely unquestioned ideas, norms and rules needs further research. The performance of an institution, e.g., the legal order, depends upon how individuals and the community react to it. Individual behaviour and institutional performance limit the possible continuation of a regime path.

Beyond a doubt, the conceptual framework of labour regimes calls for additional refinement, operationalisation and empirical research. Our contribution has been a first and tentative application of the concept to the research area of the Chinese labour market. Conclusions rely on judgements drawn from our own earlier research on labour and relevant literature. In a further step it is necessary to carry out empirical tests on the interrelatedness of the ensemble of institutions in the labour regime or the mapping of plausible clusters that have proved its potential in welfare regime analysis. 


\section{References}

Ahmad, Ehtisham and Athar Hussain (1991), 'Social Security in China: A Historical Perspective', in: Ahmad, Ehtisham, Jean Drèze, John Hills and Armatya Sen (eds.), Social Security in Developing Countries, Oxford, pp. 247-304.

Anagnost, Ann (2004), 'The Corporeal Politics of Quality (Suzhi)', in: Public Culture, 16, 2, pp. 189-208.

Andreß, Hans-Jürgen and Thorsten Heien (2001), 'Four Worlds of Welfare State Attitudes? A Comparison of Germany, Norway, and the United States', in: European Sociological Review, 17, 4, pp. 337-356.

Bardhan, Pranab (2005), 'Institutions matter, but which ones?', in: Economics of Transition, 13, 3, pp. 499-532.

Braverman, Harry (1976), Labor and monopoly capital: The degradation of work in the 20th century, New York.

Cai, Fang, Yang Du and Meiyan Wang (2005), Zhongguo laodongli shichang zhuanxing yu fayu [How Close is China to a Labor Market], Beijing.

Cai, Qian (2003), 'Migrant Remittances and Family Ties: A Case Study in China', in: International Journal of Population Geography, 9, pp. 471-483.

Chen, Feng (2003), 'Between the State and Labour: the Conflict of Chinese Trade Unions' Double Identity in Market Reform', in: The China Quarterly, December, pp. 1006-1028.

Clarke, Simon and Chang-Hee Lee (o.J. (2002)), 'Towards a System of Tripartite Consultation in China?', in: www.warwick.ac.uk/ syrbe/china/Tripartism\%20paper.pdf (access 29.12.2004).

Clarke, Simon, Chang-Hee Lee and Qi Li (2004), 'Collective Consultation and Industrial Relations in China', in: British Journal of Industrial Relations, 42, 2, pp. 235-254.

Crouch, Colin (2005), 'Die Bedeutung von Governance für Vielfalt und Wandel im modernen Kapitalimus', in: Miller, Max (ed.): Welten des Kapitalismus. Institutionelle Alternativen in der globalisierten Ökonomie, Frankfurt/New York, pp. 101-126.

Deng, Zhong and Donald J. Treiman (1997), 'The Impact of the Cultural Revolution on the Trends in Educational Attainment in the People's Republic of China', in: American Journal of Sociology, 103, 2, pp. 391-428.

Ebbinghaus, Bernhard (2005), Can Path Dependence Explain Institutional Change? Two Approaches Applied to Welfare State Reform. MPIfG Discussion Paper 05/2. Max-PlanckInstitut für Gesellschaftsforschung. Köln 
Ebbinghaus, Bernhard and Philip Manow (2001), 'Introduction: Studying Varieties of Capitalism', in: Ebbinghaus, Bernhard and Manow Philip (eds.), Comparing Welfare Capitalism. Social Policy and Political Economy in Europe, Japan and the USA, London, pp. 1-22.

Esping-Andersen, Gøsta (1990), The Three Worlds of Welfare Capitalism, Princeton/New Jersey.

Esping-Andersen, Gösta (1994), 'Welfare States and the Economy', in: Smelser, Neil J. and Richard Swedberg (eds.), Handbook of Economic Sociology, Princeton, pp. 711-732.

Esping-Andersen, Gøsta and Marino Regini (2000), Why deregulate labour markets? Oxford [u.a.].

Galasi, Peter and György Sziraczki (1985) (eds.), Labour Market and Second Economy in Hungary. Frankfurt/M., New York.

Gao, Qin (2006), 'The Social Benefit System in Urban China: Reforms and Trends from 1988 to 2002', in: Journal of East Asian Studies, 6, pp. 31-67.

Geffken, Rolf (2003a), 'Arbeitsrecht in China: Soft-Law oder Steuerung? Teil 1', in: China aktuell, Oktober, pp. 1241-1253.

Geffken, Rolf (2003b), 'Arbeitsrecht in China: Soft-Law oder Steuerung? Teil 2', in: China aktuell, November, pp. 1354-1364.

Goodman, Roger, Gordon White and Huck-ju Kwon (1998), The East Asian Welfare Model: Welfare Orientalism and the State, London.

Granovetter, Mark S. (1985), 'Economic Action and Social Structure: the Problem of Embeddedness', in: American Journal of Sociology, 91, 3, pp. 481-510.

Grünert, Holle and Burkart Lutz (1994), 'Transformationsprozeß und Arbeitsmarktsegmentation', in: Nickel, Hildegard Maria (ed.), Erwerbsarbeit und Beschäftigung im Umbruch, Berlin, pp. 3-28.

Hanser, Amy (2005), 'The Gendered Rice Bowl. The Sexual Politics of Service Work in Urban China', in: Gender and Society, 19, 5, pp. 581-600.

Hayhoe, Ruth (1992) (ed.), Education and Modernization. The Chinese Experience. Oxford; New York; Seoul; Tokyo.

He, Faping (2003), Struktur und Funktionsweise des chinesischen Arbeitsmarktes. Der Gestaltungsprozess des Arbeitsmarktes unter dem wirtschaftlich-sozialen Strukturwandel in der VR China seit 1978. Frankfurt a.M. et al.

Hebel, Jutta (2005), 'Konturen einer neuen Arbeitsgesellschaft: Transformationsprozess in der VR China', in: Soziale Welt, 56, 1, pp. 17-38. 
Hebel, Jutta (1997), Chinesische Staatsbetriebe zwischen Plan und Markt. Von der 'Danwei' zum Wirtschaftsunternehmen, Hamburg.

Hebel, Jutta and Günter Schucher (forthcoming), 'Beschäftigungsstrukturen und Arbeitsmärkte: Chinas Übergang zur marktvermittelten Erwerbsarbeit', in: Fischer, Doris et al. (eds.), Länderbericht China.

Hebel, Jutta and Günter Schucher (2006), 'Flexibility and Security in China's Emerging Socialist Market Labour Regime', in: Baur, Michaela et al. (eds.), Labor Mobility in Urban China. An Integrated Labor Market in the Making, Shanghai, pp. 19-49.

Hebel, Jutta and Günter Schucher (2004), Interviews with Chinese labour market experts in Beijing, Shanghai and Nanjing (unpublished).

Hebel, Jutta and Günter Schucher (1999) (eds.), Der chinesische Arbeitsmarkt. Strukturen, Probleme, Perspektiven, Hamburg.

Hebel, Jutta and Günter Schucher, (1992), Zwischen Arbeitsplan und Arbeitsmarkt. Strukturen des Arbeitssystems in der VR China, Hamburg.

Heidenreich, Martin (2000). 'Beschäftigungsordnungen in Europa'. [retrieved 29.06. 2005]. Available from www.uni-bamberg.de/sowi/europastudien/employlong.htm.

Heidenreich, Martin (2004). 'Beschäftigungsordnungen zwischen Exklusion und Inklusion. Arbeitsmarktregulierende Institutionen im internationalen Vergleich.' in Zeitschrift für Soziologie, 33, no. 3, (Juni), 206-227.

Jacka, Tamara (1990), ‘Back To The Wok: Women And Employment In Chinese Industry in the 1980', in: The Australian Journal of Chinese Affairs, 24, pp. 2-23.

Jackson, Sukhan (1992), Chinese Enterprise Management. Reforms in Economic Perspective, Berlin, New York.

Johnson, Kay Ann (1983), Women, the Family and Peasant Revolution in China, Chicago; London.

Kim, Yeon Myung (2005), 'The Re-examination of East Asian Welfare Regime. Methodological Problems in Comparing Welfare States and the Possibility of Classifying East Asian Welfare Regimes', www.welfareasia.org/ws1/data/contribution_YM\%20Kim2.doc (access 29.05.2005).

Knell, Mark and Martin Srholec (2006), 'Emerging Varieties of Capitalism in Central and Eastern Europe'. www.paisley.ac.uk/business/cces/documents/KnellSrholec.pdf

Knight, John and Lina Song (2005), Towards a Labour Market in China, Oxford.

Kong, Tat Yan (2006), 'Globalization and Labour Market Reform: Patterns of Response in Northeast Asia', in: British Journal of Political Science, 36, pp. 359-383. 
Kornai, Janos (1980), “Hard' and 'Soft' Budget Constraint', in: Acta Oeconomica, 25, 3-4, pp. 231-246.

Logan, John R., Yanjie Bian and Fuqin Bian (1999), 'Housing Inequality in Urban China in the 1990s', in: International Journal of Urban and Regional Research, 23, 1, pp. 7-25.

Logan, John R., Fuqin Bian and Yanjie Bian (1998), 'Tradition and Change in the Urban Chinese Family: The Case of Living Arrangements', in: Social Forces, 76, 3, pp. 851-882.

Lu, Ming, Jianyong Fan, Shejian Liu and Yan Yan (2002), 'Employment restructuring during China's economic transition', in: Monthly Labor Review, August, pp. 25-31.

Lutz, Burkart (1987), Arbeitsmarktstruktur und betriebliche Arbeitskräftestrategie: eine theoretisch-historische Skizze zur Entstehung betriebszentrierter Arbeitsmarktsegmentation, Frankfurt am Main.

Page, Scott E. (2006), 'Path Dependence', in: Quarterly Journal of Political Science, 1, pp. 87115.

Page, Scott E. and Jenna Bednar (2006), 'Culture, Institutional Performance and Path Dependence'. WP2006-6. Institute of Governmental Studies. Berkeley

Pei, Xiaolin (2005), 'The Genesis of China's Economic Transition', in: China Information, XIX, 1, pp. 5-38.

Pfau-Effinger, Birgit (1997), 'Zum theoretischen Rahmen für die Analyse internationaler Differenzen in der gesellschaftlichen Integration von Frauen', in: Hradil, Stefan (ed.), Differenz und Integration. Die Zukunft moderner Gesellschaften, Frankfurt/Main; New York, pp. 514-527.

Pfau-Effinger, Birgit (2001), ‘Wandel wohlfahrtsstaatlicher Geschlechterpolitiken im soziokulturellen Kontext', in: Heintz, Bettina (ed.), Geschlechtersoziologie, Wiesbaden, pp. 487511.

Pimentel, Ellen Efron and Jinyun Liu (2004), 'Exploring Nonnormative Coresidence in Urban China: Living With Wives' Parents', in: Journal of Marriage and Family, 66, August, pp. 821-836.

Putterman, Louis and Xiao-Yuan Dong (2000), 'China's State-Owned Enterprises. Their Role, Job Creation, and Efficiency in Long-Term Perspective', in: Modern China, 26, 4, pp. 403447.

Schucher, Günter (2006). 'Chinas neues Arbeitsvertragsgesetz - Stärkung der Schwachen oder nur Beruhigungspille?', in: China aktuell, 4, pp. 47-65.

Selden, Mark and Laiyin You (1997), 'The Reform of Social Welfare in China', in: World Development, 25, 10, pp. 1657-1668. 
Sengenberger, Werner (1978), Der gespaltene Arbeitsmarkt: Probleme der Arbeitsmarktsegmentation, Frankfurt am Main.

Shaw, Victor N. (1996), Social Control in China. A Study of Chinese Work Units, Westport.

Shirk, Susan (1981), 'Recent Chinese Labour Policies and the Transformation of Industrial Organization', in: China Quarterly, 88, pp. 575-593.

Vodopivec, Milan (1991), 'The Labor Market and the Transition of Socialist Economies', in: Comparative Economic Studies, 33, 2, pp. 123-158.

Walder, Andrew G. (1988), Communist Neo-Traditionalism. Work and Authority in Chinese Industry, Berkeley; Los Angeles; London.

Wang, Fei-Ling (2005), Organizing Through Division and Exclusion. China's Hukou System, Stanford.

White, Gordon, Roger Goodman and Huck-ju Kwon (1998), The East Asian Welfare Model. Welfare Orientalism and the State, London.

White Paper (2004a), 'China' Social Security and Its Policy'. Beijing, in: www.china.org.cn.

White Paper (2004b), 'China's Employment Situation and Policies. Information Office of the State Council of the People's Republic of China'. Beijing, in: www.china.org.cn/ewhite/20040426/index.htm.

Willmann, Katrin and Günter Schucher (2005), 'Facts about and Development in the Rural Education of the PRC', in: China aktuell, 5, pp. 10-15.

Yang, Yiyong (2002), Zhongguo zhuangui shiqi de jiuye wenti (The Employment in the Transition Period of China), Beijing.

Zhang, Qian Forrest (2004), 'Economic Transition and New Patterns of Parent-Adult Child Coresidence in Urban China', in: Journal of Marriage and Family, 66, Dec., pp. 1231-1245. 


\section{G

\section{Recent issues:}

No 38 Barbara Fritz and Laurissa Mühlich: Regional Monetary Integration among Developing Countries: New Opportunities for Macroeconomic Stability beyond the Theory of Optimum Currency Areas?; December 2006

No 37 Andreas Ufen: Political Parties in Post-Suharto Indonesia: Between politik aliran and 'Philippinisation'; December 2006

No 36 Juliane Brach: Ten Years after: Achievements and Challenges of the Euro-Mediterranean Economic and Financial Partnership; December 2006

No 35 Christian von Soest: Measuring the Capability to Raise Revenue. Process and Output Dimensions and Their Application to the Zambia Revenue Authority; December 2006

No 34 Sebastian Huhn, Anika Oettler and Peter Peetz: Construyendo Inseguridades. Aproximaciones a la violencia en Centroamérica desde el análisis del discurso [Constructed insecurities. Discourse analysis and the understanding of violence in Central America]; November 2006

No 33 Sebastian Huhn, Anika Oettler and Peter Peetz: Exploding Crime? Topic Management in Central American Newspapers; November 2006

No 32 Christian von Soest: How Does Neopatrimonialism Affect the African State? The Case of Tax Collection in Zambia; November 2006

No 31 Susan Steiner: Decentralisation in Uganda: Exploring the Constraints for Poverty Reduction; November 2006

No 30 Detlef Nolte: Potencias regionales en la política internacional: conceptos y enfoques de análisis [Regional Powers in International Relations: Analytical Concepts and Research Approaches]; October 2006

No 29 Detlef Nolte: Macht und Machthierarchien in den internationalen Beziehungen: Ein Analysekonzept für die Forschung über regionale Führungsmächte [Power and Power Hierarchies in International Relations: Towards an Analytical Concept for the Study of Regional Powers]; October 2006

No 28 Bert Hoffmann and Laurence Whitehead: Cuban Exceptionalism Revisited; September 2006

No 27 Andreas Mehler: Political Discourse in Football Coverage - The Cases of Côte d'Ivoire and Ghana; August 2006

No 26 Martin Beck: Probleme des Rentierstaats-Ansatzes in vergleichender Perspektive [Problems of the Rentier State Approach in Comparative Perspective]; August 2006

All GIGA Working Papers are available free of charge at www.giga-hamburg.de/workingpapers. For any requests please contact: workingpapers@giga-hamburg.de.

Editor of the Working Paper Series: Bert Hoffmann. 